\title{
ANALYSIS OF OPERATING TEMPERATURE OF THE POLYCRYSTALLINE SOLAR CELL
}

\author{
Vladimír GÁLL, Alexander MÉSZÁROS, Ján TKÁČ \\ Department of Electric Power Engineering, Faculty of Electrical Engineering and Informatics, \\ Technical University of Košice, Letná 9, 04200 Košice, Slovak Republic, \\ E-mail: vladimir.gall@student.tuke.sk, alexander.meszaros@tuke.sk,jtk1235@gmail.com
}

\begin{abstract}
This work deals with the solar cells with orientation on the calculation of operating temperature of the polycrystalline solar cell, which is under actual load. Operating conditions have a significant effect on the efficiency of solar cells. In the summer with increasing temperature, the efficiency decreases. In the winter, efficiency and output voltage are rising. The operating temperature is determined by intensity of solar radiation, the types of materials used by construction and operating condition. The aim of this work was simplify of the calculation of operating temperature of solar cells. The result of this work is a derived equation that allows a more accurate and faster calculation this temperature with using Matlab software.
\end{abstract}

Keywords: conductor, copper, current, initial temperature of wire, operating temperature, polycrystalline solar cell, temperature of environment, silicon, semiconductor

\section{INTRODUCTION}

One of the important operating factors of solar cells is their temperature, which has a significant seasonal effect on energy gain. The temperature of the solar cells is mainly influenced by the intensity of the sun's radiation and the temperature of environment. Increasing operating temperature also contributes electric current flowing through the solar cell. The generated heat is carried away from the solar cell into the environment. While the maximum surface temperature is relatively small, the proportion of heat emitted by the radiation is relatively small compared to the thermal conductivity of the surrounding materials [1], [2]. The resulting operating temperature of the solar cell is given by the balance between the heat produced and the heat consumed for heating the solar cells and the heat diverted to the environment [3], [4]. Heat ratios change significantly seasonally. In summer, sunlight is high, the temperature of environment reaches more than $30^{\circ} \mathrm{C}$, and the temperature of solar cells up to around $60^{\circ} \mathrm{C}$, in winter is low temperature of environment but the efficiency of solar cells is high [5], [6]. Two main materials are used in solar cell, silicon as semiconductor and copper as conductor [7].

\section{EQUATION FOR CALCULATION OF OPERATING TEMPERATURE}

When a current I flows through the wire in time dt produces the heat $\mathrm{dQ}$, part of this heat consumed to heating of the wire as $\mathrm{dQ}_{1}$ and the other part of this heat diverts to environment as $\mathrm{dQ}_{2}$. When a current I flows through the wire with resistance $\mathrm{R}_{9}$ then in time $\mathrm{dt}$ develop the heat dQ defined by equation:

$d Q=R_{\vartheta} I^{2} d t=R_{0} I^{2}\left(1+\alpha_{R} \Delta \vartheta_{0}\right) d t=\frac{\rho_{R} l I^{2}}{S}\left(1+\alpha_{R} \Delta \vartheta_{0}\right) d t$

Where $R_{0}$ is resistance of wire for difference of elementary temperature $\Delta \vartheta_{0}$ and 1 is length of wire. Part of the heat $\mathrm{dQ}_{1}$ consumed for heating the material and temperature change about $\mathrm{d}(\Delta \vartheta)$ :

$d Q_{1}=m c d(\Delta \vartheta)=V \rho_{m} c d(\Delta \vartheta)=S l \rho_{m} c d(\Delta \vartheta)$

Where $\mathrm{m}$ is mass and $\mathrm{V}$ is volume of the wire. The part of the heat $\mathrm{dQ}_{2}$ diverted to environment in time $\mathrm{dt}$ :

$d Q_{2}=\lambda S_{P} \Delta \vartheta d t=\lambda o l \Delta \vartheta d t$

Where $S_{P}$ is lateral surface area of wire. Other symbols are explained in Table 1. Perpetual balance of heat energy is defined by differential equation:

$d Q=d Q_{1}+d Q_{2}$

After substitution the previous equations (1), (2), (3) into equation (4) we get a new differential equation:

$\frac{\rho_{R} I^{2} l}{S}\left(1+\alpha_{R} \Delta \vartheta_{0}\right) d t=S \rho_{m} c l d(\Delta \vartheta)+\lambda o l \Delta \vartheta d t$

$\frac{\rho_{R} I^{2}}{S}\left(1+\alpha_{R} \Delta \vartheta_{0}\right) d t=S \rho_{m} c d(\Delta \vartheta)+\lambda o \Delta \vartheta d t$

$\frac{\rho_{R} I^{2}}{S}\left(1+\alpha_{R}\left(\Delta \vartheta+\Delta \vartheta_{W}\right)\right) d t=S \rho_{m} c d(\Delta \vartheta)+\lambda o \Delta \vartheta d t$

From the equation (7) we can express dt:

$$
\begin{aligned}
d t= & \frac{S \rho_{m} c d(\Delta \vartheta)}{\frac{\rho_{R} I^{2}\left(1+\alpha_{R} \Delta \vartheta_{W}\right)}{S}-\Delta \vartheta\left(\lambda o-\frac{\rho_{R} I^{2} \alpha_{R}}{S}\right)} \\
d t= & \frac{\frac{S \rho_{m} c d(\Delta \vartheta)}{\lambda o-\frac{\rho_{R} I^{2} \alpha_{R}}{S}}}{\frac{\rho_{R} I^{2}\left(1+\alpha_{R} \Delta \vartheta_{W}\right)}{S}}-\Delta \vartheta \\
& \frac{\rho_{R} I^{2} \alpha_{R}}{S}
\end{aligned}
$$

(9)

This differential equation (9) can be simplified by 
introducing the following substitutions:

$$
\begin{aligned}
& A=S \rho_{m} c \\
& B=\frac{\rho_{R} I^{2}\left(1+\alpha_{R} \Delta \vartheta_{W}\right)}{S} \\
& D=\lambda o-\frac{\rho_{R} I^{2} \alpha_{R}}{S}
\end{aligned}
$$

After substitution (10), (11), (12) into (9) we get next equation:

$$
d t=\frac{\frac{A}{D} d(\Delta \vartheta)}{\frac{B}{D}-\Delta \vartheta}
$$

We are using another substitution:

$$
\begin{aligned}
& Z=\frac{B}{D}-\Delta \vartheta \\
& d Z=-d(\Delta \vartheta)
\end{aligned}
$$

After a substitution (14) and (15) into (13) we get:

$$
d t=\frac{-\frac{A}{D} d Z}{Z}
$$

With helping this substitution we can solve the integral:

$$
\begin{aligned}
& t=\int_{0}^{t} 1 d t=-\frac{A}{D} \int_{\Delta \vartheta_{E}}^{\Delta \vartheta_{p}} \frac{d Z}{Z}=-\frac{A}{D}[\ln Z]_{\Delta \vartheta_{E}}^{\Delta \vartheta_{P}}=-\frac{A}{D}\left[\ln \left(\frac{B}{D}-\Delta \vartheta\right)\right]_{\Delta \vartheta_{E}}^{\Delta \vartheta_{P}}= \\
& =-\frac{A}{D}\left(\ln \left(\frac{B}{D}-\Delta \vartheta_{P}\right)-\ln \left(\frac{B}{D}-\Delta \vartheta_{E}\right)\right)=-\frac{A}{D}\left(\ln \frac{\left(\frac{B}{D}-\Delta \vartheta_{P}\right)}{\left(\frac{B}{D}-\Delta \vartheta_{E}\right)}\right)= \\
& =-\frac{A}{D}\left(\ln \frac{\left(\frac{B-D \Delta \vartheta_{P}}{D}\right)}{\left(\frac{B-D \Delta \vartheta_{E}}{D}\right)}\right)=-\frac{A}{D}\left(\ln \left(\frac{B-D \Delta \vartheta_{P}}{B-D \Delta \vartheta_{E}}\right)\right) \\
& t=-\frac{A}{D}\left(\ln \left(\frac{B-D \Delta \vartheta_{P}}{B-D \Delta \vartheta_{E}}\right)\right)
\end{aligned}
$$

Increase of the temperature of wire $\Delta \vartheta_{\mathrm{P}}$ is a difference between operating temperature $\vartheta_{\mathrm{P}}$ and temperature of environment $\vartheta_{\mathrm{E}}$.

$$
\Delta \vartheta_{P}=\vartheta_{P}-\vartheta_{E}
$$

Initial increase of the temperature of wire $\Delta \vartheta_{E}$ is a difference between initial temperature of wire $\vartheta_{W}$ and temperature of environment $\vartheta_{\mathrm{E}}$.

$$
\Delta \vartheta_{E}=\vartheta_{W}-\vartheta_{E}
$$

Initial difference of the temperature of wire $\Delta \vartheta_{\mathrm{W}}$ is a difference between initial temperature of wire $\vartheta_{\mathrm{W}}$ and elementary temperature $\vartheta_{0}$. Elementary temperature $\vartheta_{0}$ can be found in physical tables [1], [8].

$$
\Delta \vartheta_{W}=\vartheta_{W}-\vartheta_{0}
$$

Operating difference of the temperature of wire $\Delta \vartheta$ is a difference between operating temperature $\vartheta_{\mathrm{P}}$ and initial temperature of wire $\vartheta_{\mathrm{W}}$.

$$
\Delta \vartheta=\vartheta_{P}-\vartheta_{W}
$$

In the next step equation (18) can be rewritten to this form:

$$
t\left(-\frac{D}{A}\right)=\ln \left(\frac{B-D \Delta \vartheta_{P}}{B-D \Delta \vartheta_{E}}\right)
$$

The logarithm can be from this equation removed, so equation can be written in exponential form:

$e^{-\frac{t}{\tau}}=\frac{B-D \Delta \vartheta_{P}}{B-D \Delta \vartheta_{E}}$

In the next steps, equation can be rewritten to this form:

$\Delta \vartheta_{P}=\frac{B}{D}\left(1-e^{-\frac{t}{\tau}}\right)+\Delta \vartheta_{E} e^{-\frac{t}{\tau}}$

$\Delta \vartheta_{P}=\frac{\frac{\rho_{R} I^{2}\left(1+\alpha_{R} \Delta \vartheta_{W}\right)}{S}}{\lambda o-\frac{\rho_{R} I^{2} \alpha_{R}}{S}}\left(1-e^{-\frac{t}{\tau}}\right)+\Delta \vartheta_{E} e^{-\frac{t}{\tau}}$

Initial warming constant $\tau$ is defined by this equation:

$\tau=\frac{A}{D}=\frac{S \rho_{m} c}{\lambda o-\frac{\rho_{R} I^{2} \alpha_{R}}{S}}$

After this the equation can be written like this:

$$
\Delta \vartheta_{P}=\frac{\frac{\rho_{R} I^{2}\left(1+\alpha_{R} \Delta \vartheta_{W}\right)}{S}}{\lambda o-\frac{\rho_{R} I^{2} \alpha_{R}}{S}}\left(1-e^{-\frac{t}{\lambda o-\frac{\rho \rho_{m} I^{2} \alpha_{R}}{S}}}\right)+\Delta \vartheta_{E} e^{\frac{-\frac{t}{\rho_{m} c}}{\lambda o-\frac{\rho_{R} I^{2} \alpha_{R}}{S}}}
$$

For copper as conductor resistance decreases if temperature decreases. If resistance is defined $R_{\vartheta}=0 \Omega$, then superconducting conditions are achieved. When we take account with these conditions we can write equation $\vartheta_{\mathrm{S}}=-\vartheta_{\mathrm{f}}$. For silicon as semiconductor resistance decreases, but temperature increases. A very low resistance condition is achieved, but it is not superconducting. Here for the saturation temperature and fictive temperature we can write equation $\vartheta_{S}=-\vartheta_{f}$. For this forecasts the temperature coefficient of resistance $\alpha_{R}$ can be defined:

$$
\begin{aligned}
& R_{\vartheta}=R_{0}\left(1+\alpha_{R} \Delta \vartheta_{S}\right) \\
& R_{0}\left(1+\alpha_{R} \Delta \vartheta_{S}\right)=0 \\
& 1+\alpha_{R} \Delta \vartheta_{S}=0 \\
& 1+\alpha_{R}\left(\vartheta_{S}-\vartheta_{0}\right)=0 \\
& 1=\alpha_{R}\left(\vartheta_{f}+\vartheta_{0}\right)
\end{aligned}
$$

For the temperature coefficient of resistance $\alpha_{R}$ result equation can be written to this form: 
$\alpha_{R}=\frac{1}{\vartheta_{f}+\vartheta_{0}}$

For the volumetric specific heat capacity $c_{V}$ equation can be defined like this:

$c_{V}=c \rho_{m}$

For the substitutions constant A, B, D and initial warming constant $\tau$ equations can be defined [1], [2] like this:

$A=S \rho_{m} c=S c_{V}$

$B=\frac{\rho_{R} I^{2}\left(1+\alpha_{R} \Delta \vartheta_{W}\right)}{S}=\frac{\rho_{R} I^{2}\left(1+\alpha_{R}\left(\vartheta_{W}-\vartheta_{0}\right)\right)}{S}=\frac{\rho_{R} I^{2}}{S}\left(1+\frac{\vartheta_{W}-\vartheta_{0}}{\vartheta_{f}+\vartheta_{0}}\right)$

$D=\lambda o-\frac{\rho_{R} I^{2} \alpha_{R}}{S}=\lambda o-\frac{\rho_{R} I^{2}}{S\left(\vartheta_{f}+\vartheta_{0}\right)}$

$\tau=\frac{A}{D}=\frac{S \rho_{m} c}{\lambda o-\frac{\rho_{R} I^{2} \alpha_{R}}{S}}=\frac{S \rho_{m} c}{\lambda o-\frac{\rho_{R} I^{2}}{S\left(\vartheta_{f}+\vartheta_{0}\right)}}=\frac{S c_{V}}{\lambda o-\frac{\rho_{R} I^{2}}{S\left(\vartheta_{f}+\vartheta_{0}\right)}}$

Result equation can be written to this form:

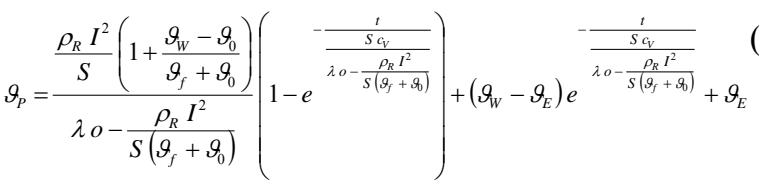

\section{CALCULATION OF OPERATING TEMPERATURE}

For the next calculation we ascertain properties of materials, which are used in polycrystalline solar cells [1], [8]. For calculation will be used silicon as semiconductor and copper as conductor. All necessary properties we can see in table.

Table 1 Properties of the materials

\begin{tabular}{|c|c|c|c|}
\hline Material & - & $\mathrm{Si}$ & $\mathrm{Cu}$ \\
\hline Specific resistance & $\varsigma_{\mathrm{R}}$ & $1.10^{-1} \Omega . m$ & $1,678.10^{-8} \Omega . \mathrm{m}$ \\
\hline Density & $\varsigma_{\mathrm{m}}$ & $2329 \mathrm{~kg} \cdot \mathrm{m}^{-3}$ & $8960 \mathrm{~kg} \cdot \mathrm{m}^{-3}$ \\
\hline Specific heat capacity & $\mathrm{c}$ & $704,5984583 \mathrm{~J} \cdot \mathrm{kg}^{-1} \cdot{ }^{\circ} \mathrm{C}^{-1}$ & $383 \mathrm{~J}^{\mathrm{kg}}{ }^{-1} \cdot{ }^{\circ} \mathrm{C}^{-1}$ \\
\hline Volumetric specific heat capacity & $\mathrm{cv}$ & $1641009,809 \mathrm{~J}^{-3}{ }^{-3} \cdot{ }^{\circ} \mathrm{C}^{-1}$ & $3431680 \mathrm{~J}^{-\mathrm{m}^{-3}} \cdot{ }^{\circ} \mathrm{C}^{-1}$ \\
\hline Fictive temperature & Ye & $-47,100271^{\circ} \mathrm{C}$ & $234,5^{\circ} \mathrm{C}$ \\
\hline Elementary temperature of environment & $9_{0}$ & $20{ }^{\circ} \mathrm{C}$ & $20^{\circ} \mathrm{C}$ \\
\hline Temperature coefficient of resistance & $\alpha_{R}$ & $-3,69.10^{-2}{ }^{\circ} \mathrm{C}^{-1}$ & $3,929273084 \cdot 10^{-3}{ }^{\circ} \mathrm{C}^{-1}$ \\
\hline Coefficient of thermal expansion & $\alpha_{\mathrm{L}}$ & $2.10^{-6}{ }^{\circ} \mathrm{C}^{-1}$ & $1,65.10^{-5}{ }^{\circ} \mathrm{C}^{-1}$ \\
\hline Section & $\mathrm{s}$ & $2,4336.10^{-2} \mathrm{~m}^{2}$ & $1.10^{-6} \mathrm{~m}^{2}$ \\
\hline Circumference & o & $6,24.10^{-1} \mathrm{~m}$ & $5.10^{-3} \mathrm{~m}$ \\
\hline Dimension & $\mathrm{x}$ & $0,156 \mathrm{~m}$ & $5.10^{-4} \mathrm{~m}$ \\
\hline Dimension & $\mathrm{y}$ & $0,156 \mathrm{~m}$ & $2.10^{-3} \mathrm{~m}$ \\
\hline Coefficient of heat transfer & $\lambda$ & $10 \mathrm{~W} \cdot{ }^{\circ} \mathrm{C}^{-1} \cdot \mathrm{m}^{-2}$ & $10 \mathrm{~W} \cdot{ }^{\circ} \mathrm{C}^{-1} \cdot \mathrm{m}^{-2}$ \\
\hline
\end{tabular}

In the next graphs are shown calculated values of operating temperature $\vartheta_{\mathrm{P}}$ in dependence on time $t$. For calculations is used equation (40). These graphs are made for different current I which flow through polycrystalline solar cell. Initial temperature of wire $\vartheta_{\mathrm{W}}$ is the same than temperature of environment $\vartheta_{\mathrm{E}}$. Fig. 1 and Fig. 3 are for silicon, Fig. 2 and Fig. 4 are for copper. Fig. 1 and Fig. 2 are for the current $\mathrm{I}=8,36 \mathrm{~A}$, Fig. 3 and Fig. 4 are for the current $\mathrm{I}=4,18 \mathrm{~A}$.

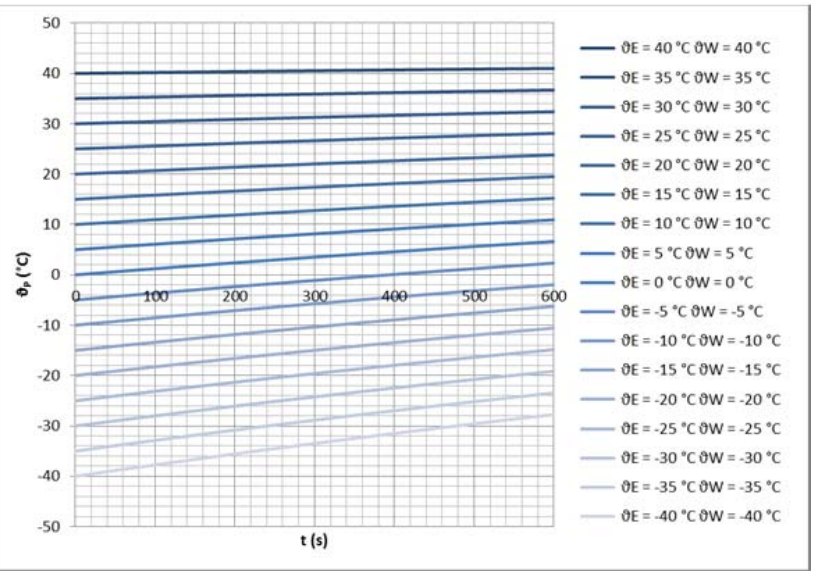

Fig. 1 Calculated operating temperatures $\vartheta_{\mathrm{P}}$ for the current $\mathrm{I}=8,36 \mathrm{~A}$ for the silicon

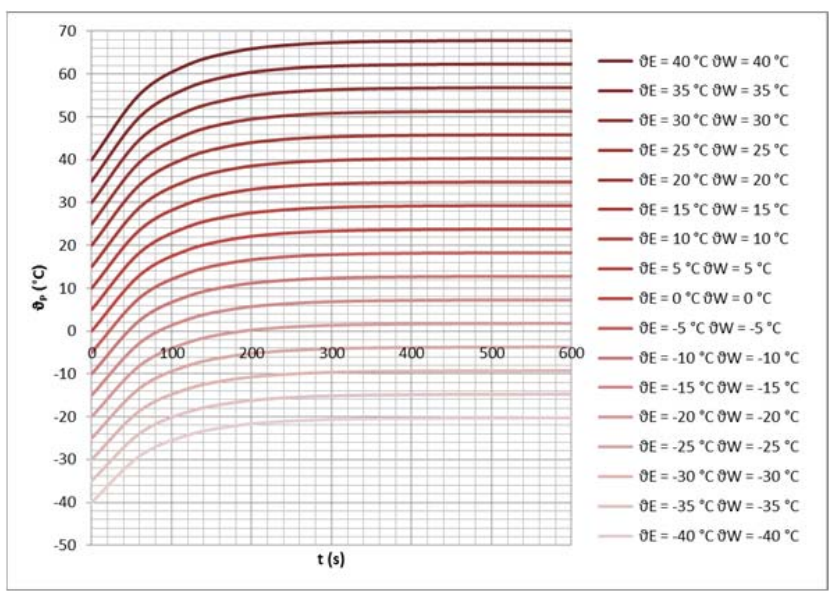

Fig. 2 Calculated operating temperatures $\vartheta_{\mathrm{p}}$ for the current $\mathrm{I}=8,36 \mathrm{~A}$ for the copper

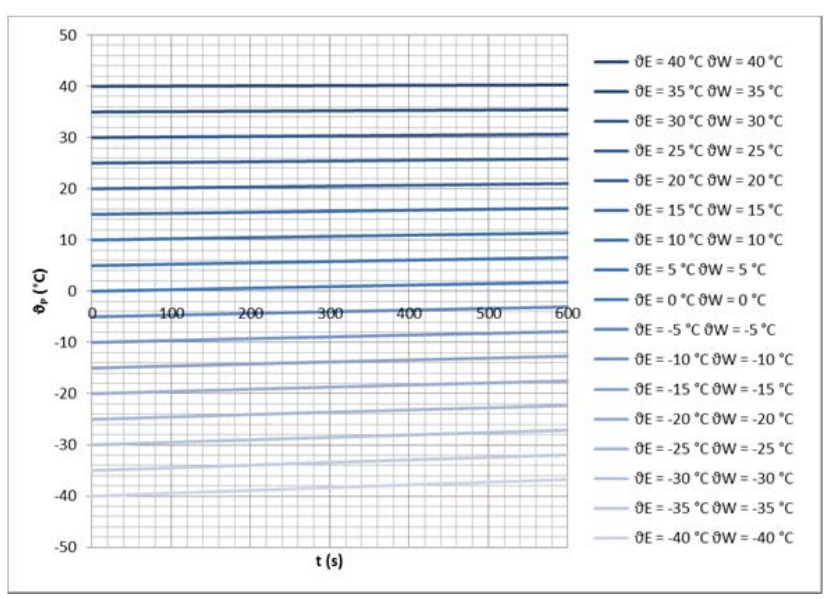

Fig. 3 Calculated operating temperatures $\vartheta_{\mathrm{p}}$ for the current $\mathrm{I}=4,18 \mathrm{~A}$ for the silicon

The main influence for current I has solar radiation. The average current I of the solar cell can be ascertained for every single month [9]. The average current I of polycrystalline solar cell was measured in each month at the time of maximum sunlight about 12 hours, for the clear sky. Results are shown in Fig. 5 [10]. 


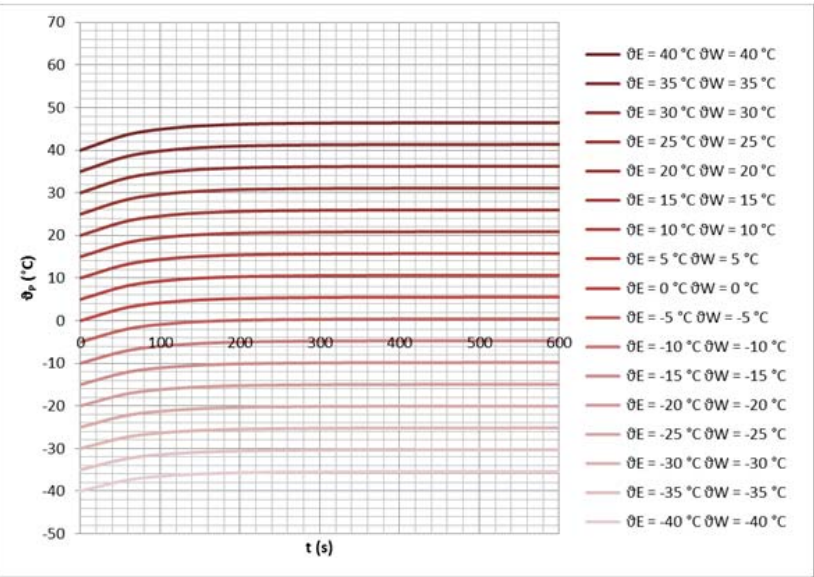

Fig. 4 Calculated operating temperatures $\vartheta_{\mathrm{p}}$ for the current $\mathrm{I}=4,18 \mathrm{~A}$ for the copper

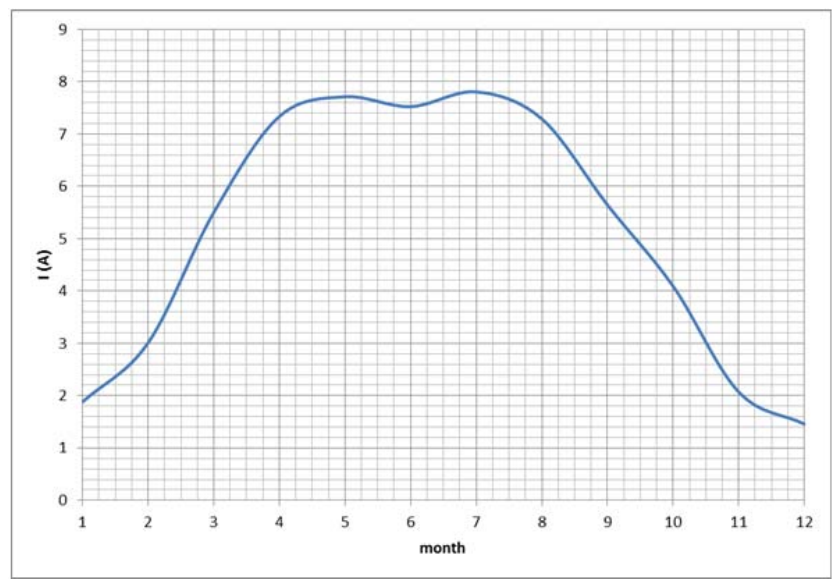

Fig. 5 The average current I

For calculation of operating temperature $\vartheta_{\mathrm{P}}$, the equality of temperature of environment $\vartheta_{\mathrm{E}}$ and initial temperature of material $\vartheta_{\mathrm{W}}$ can be supposed. Here is used equation (40) and calculations are made in time $t=600 \mathrm{~s}$. For the calculation of operating temperature $\vartheta_{\mathrm{P}}$ is needed the knowladge of the temperature of environment $\vartheta_{\mathrm{E}}$. In these pictures are shown the influence of temperature of environment $\vartheta_{\mathrm{E}}$ and current I to the operating temperature $\vartheta_{\mathrm{P}}$. The temperature of environment $\vartheta_{\mathrm{E}}$ was ascertained as average temperature for every single month in four Slovak

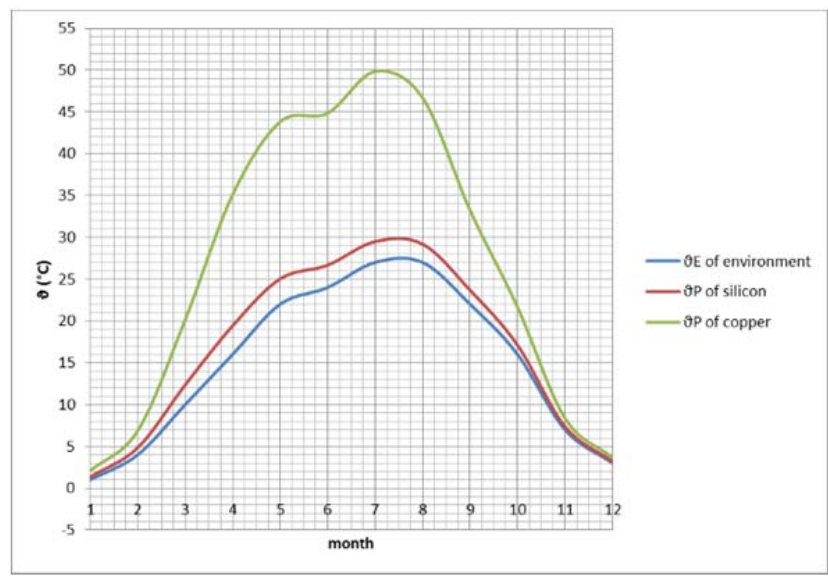

Fig. 6 The temperature of environment $\vartheta_{\mathrm{E}}$ and calculation of the operating temperature $\vartheta_{\mathrm{p}}$ in Bratislava towns Bratislava, Košice, Poprad, Žilina and Italian town Bologna. Maximal values of operating temperature $\vartheta_{\mathrm{P}}$ were achieved in summer and minimal values of operating temperature $\vartheta_{\mathrm{P}}$ were achieved in winter.

Slovak town with warmer climate is Bratislava [11]. These calculations of operating temperature $\vartheta_{\mathrm{P}}$ are shown in Fig. 6 for silicon and copper. Maximal value of operating temperature $\vartheta_{\mathrm{p}}$ for copper is $49,8412{ }^{\circ} \mathrm{C}$ and for silicon is $29,4895{ }^{\circ} \mathrm{C}$. Minimal value of operating temperature $\vartheta_{\mathrm{P}}$ for copper is $2,1037{ }^{\circ} \mathrm{C}$ and for silicon is $1,3533{ }^{\circ} \mathrm{C}$.

Another Slovak town with warmer climate is Košice [11]. These calculations of operating temperature $\vartheta_{\mathrm{P}}$ are shown in Fig. 7 for silicon and copper. Maximal value of operating temperature $\vartheta_{\mathrm{P}}$ for copper is $48,7539^{\circ} \mathrm{C}$ and for silicon is $28,6134{ }^{\circ} \mathrm{C}$. Minimal value of operating temperature $\vartheta_{\mathrm{P}}$ for copper is $0,0944{ }^{\circ} \mathrm{C}$ and for silicon is $-0,6314^{\circ} \mathrm{C}$.

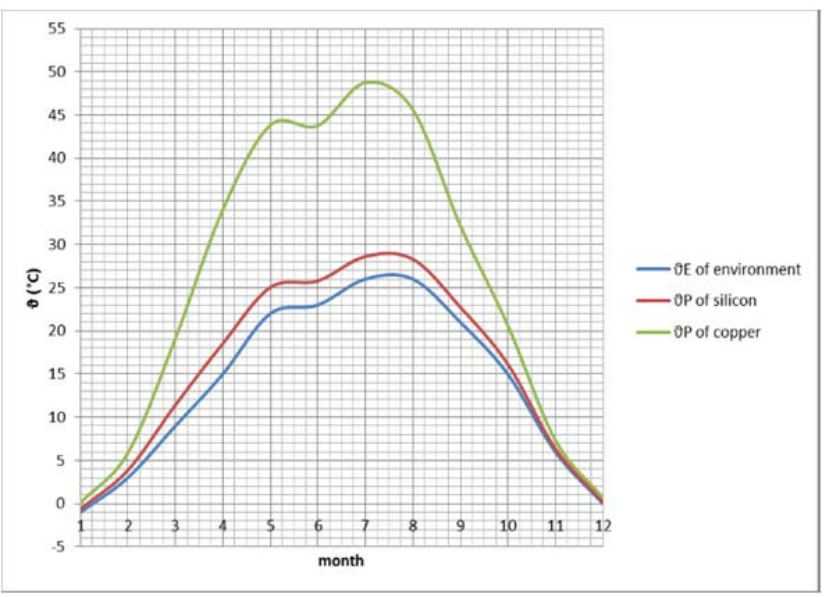

Fig. 7 The temperature of environment $\vartheta_{\mathrm{E}}$ and calculation of the operating temperature $\vartheta_{\mathrm{p}}$ in Košice

Slovak town with cooler climate is Poprad [11]. These calculations of operating temperature $\vartheta_{\mathrm{P}}$ are shown in Fig. 8 and for silicon and copper. Maximal value of operating temperature $\vartheta_{\mathrm{P}}$ for copper is $44,4045{ }^{\circ} \mathrm{C}$ and for silicon is $25,6249{ }^{\circ} \mathrm{C}$. Minimal value of operating temperature $\vartheta_{\mathrm{P}}$ for copper is $-0,3439{ }^{\circ} \mathrm{C}$ and for silicon is $-0,7783{ }^{\circ} \mathrm{C}$.

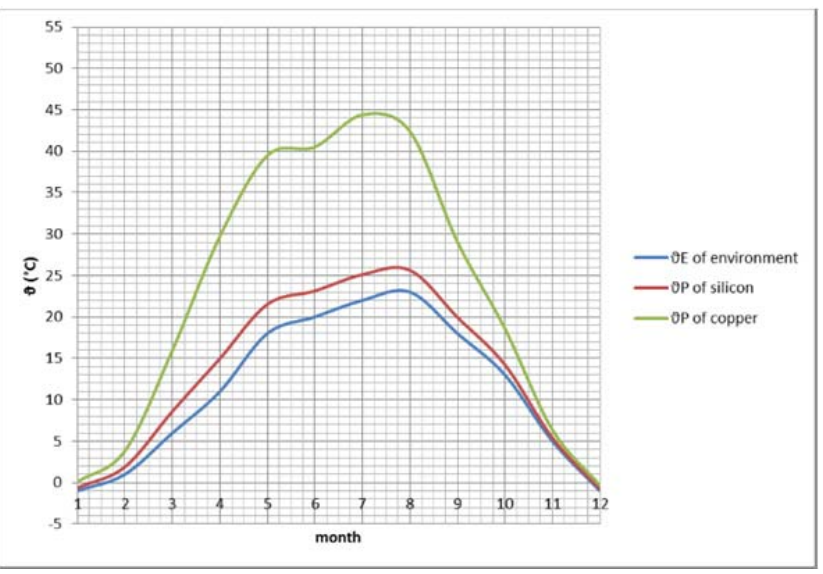

Fig. 8 The temperature of environment $\vartheta_{\mathrm{E}}$ and calculation of the operating temperature $\vartheta_{\mathrm{P}}$ in Poprad 
Another Slovak town with cooler climate is Žilina [11]. These calculations of operating temperature $\vartheta_{P}$ are shown in Fig. 9 for silicon and copper. Maximal value of operating temperature $\vartheta_{\mathrm{P}}$ for copper is $42,2298^{\circ} \mathrm{C}$ and for silicon is $23,8427{ }^{\circ} \mathrm{C}$. Minimal value of operating temperature $\vartheta_{\mathrm{P}}$ for copper is $-1,3467{ }^{\circ} \mathrm{C}$ and for silicon is $-1,7736^{\circ} \mathrm{C}$.

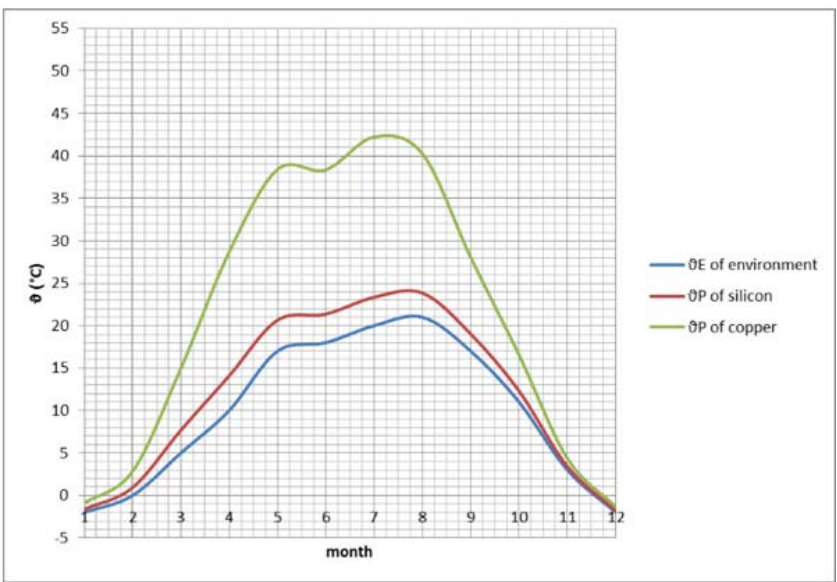

Fig. 9 The temperature of environment $\vartheta_{\mathrm{E}}$ and calculation of the operating temperature $\vartheta_{\mathrm{P}}$ in Žilina

For example is reported town in southern country with warmer climate. Here was chosen Italian town Bologna [12]. These calculations of operating temperature $\vartheta_{\mathrm{p}}$ are shown in Fig. 10 for silicon and copper. Maximal value of operating temperature $\vartheta_{\mathrm{P}}$ for copper is $51,9072{ }^{\circ} \mathrm{C}$ and for silicon is $31,1542{ }^{\circ} \mathrm{C}$. Minimal value of operating temperature $\vartheta_{\mathrm{P}}$ for copper is $4,0126{ }^{\circ} \mathrm{C}$ and for silicon is $3,2387^{\circ} \mathrm{C}$

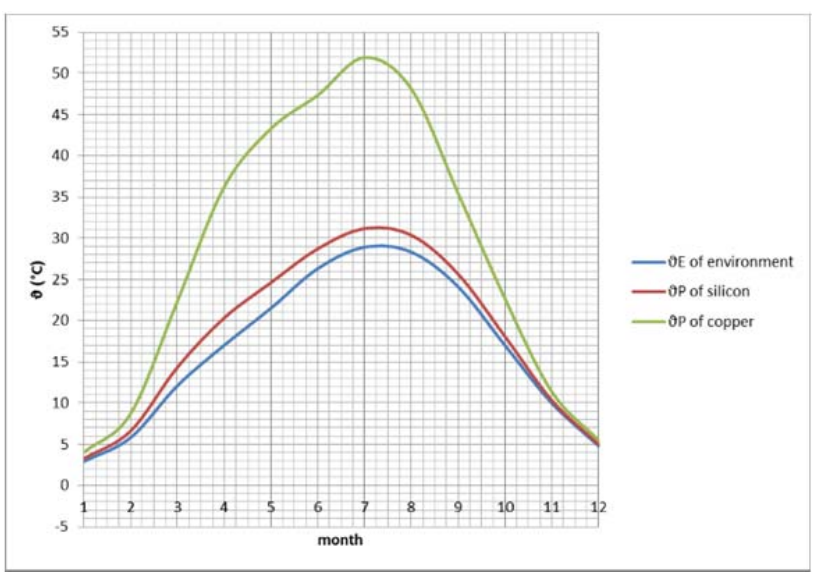

Fig. 10 The temperature of environment $\vartheta_{\mathrm{E}}$ and calculation of the operating temperature $\vartheta_{\mathrm{P}}$ in Bologna

For comparison of results, the temperature of environment $\vartheta_{\mathrm{E}}$ was ascertained as average temperature for every single month in Italian town Bologna and the measured results from model described in article can be used [12]. Here is used nominal value of current I of polycrystalline solar cell and it is $8,36 \mathrm{~A}$. At the same time, it is necessary to take into account the previous operation of the solar cell. In this comparison is supposed that, the initial temperature of material $\vartheta_{\mathrm{W}}$ is $8{ }^{\circ} \mathrm{C}$ higher than the temperature of environment $\vartheta_{\mathrm{E}}$. Here is used equation (40) and calculations are made in time $t=1200 \mathrm{~s}$. In case 1 , temperature $\vartheta_{M}$ was measured on the glass of the solar panel. In case 2 , temperature $\vartheta_{M}$ was measured on the surface of solar cell next to copper wire.

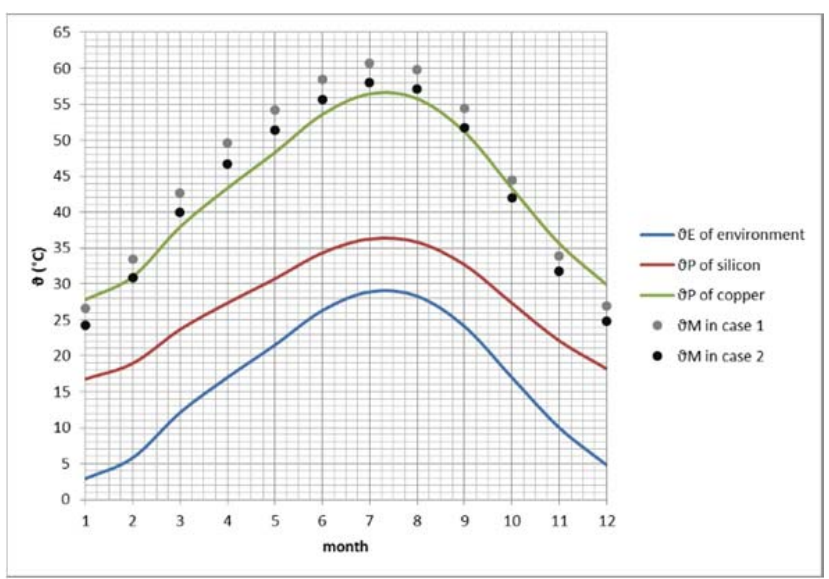

Fig. 11 The temperature of environment $\vartheta_{\mathrm{E}}$, calculation of the operating temperature $\vartheta_{\mathrm{P}}$ and measured temperatures $\vartheta_{\mathrm{M}}$ in Bologna

\section{CONCLUSION}

For the calculating the operating temperature $\vartheta_{\mathrm{p}}$ of the solar cells is used equation (40). This new equation successfully shows influence of material to operating temperature $\vartheta_{p}$. In these graphs is shown increase of operating temperature $\vartheta_{\mathrm{P}}$ in time $\mathrm{t}$. The current I have important impact to increasing of operating temperature $\vartheta_{\mathrm{P}}$. The equation (40) calculates with temperature coefficient of resistance $\alpha_{R}$. This effect is better shown, when higher current I flow through solar cell [13], [14], [15], [16]. The copper as conductor has a coefficient of resistance $\alpha_{R}$ positive and the silicon as semiconductor has a coefficient of resistance $\alpha_{R}$ negative. These differences are shown on the figures $1-4$.

The solar cells have different properties in different temperature of environment $\vartheta_{\mathrm{E}}$ and different current I. For calculations the current $I$ and the temperature of environment $\vartheta_{\mathrm{E}}$ were ascertained as average temperature for every single month. Then we expected the equality of temperature of environment $\vartheta_{\mathrm{E}}$ and initial temperature of material $\vartheta_{\mathrm{W}}$. The equation (40) calculates operating temperature $\vartheta_{\mathrm{P}}$ per month for copper as conductor and for silicon as semiconductor. These calculations are shown on the figures $6-10$.

The calculated values of operating temperature $\vartheta_{\mathrm{p}}$ for copper wire approximate to the values of measured temperature $\vartheta_{M}$ next to copper wire in case 2 . At the same time, we can consider values of operating temperature $\vartheta_{\mathrm{P}}$ for silicon, temperature of environment $\vartheta_{E}$ and measured temperature $\vartheta_{M}$ on the glass in case 1 . On the figure 11 we can see these calculations [12].

Currently, we need to verify the operating temperature $\vartheta_{p}$ of solar cells, because their efficiency by higher temperature decreasing. The ascertaining of the operating temperature $\vartheta_{\mathrm{P}}$ is important for design and efficiency of solar cells and for reliability of solar cells [17], [18], [19]. These calculations can be used also for design other semiconductor components like diodes, transistors, chips and circuit boards. 
The proposed analysis of polycrystalline solar cell can be easily expanded to take into account different scenarios of temperature of environment $\vartheta_{\mathrm{E}}$ in different towns, temperature of material $\vartheta_{\mathrm{W}}$, variation of current I according to intensity of solar radiation and other conditions that occur during the different year season.

\section{ACKNOWLEDGMENT}

This work was supported by the Scientific Grant Agency of the Ministry of Education of Slovak Republic and the Slovak Academy of Sciences under the contract No. Vega 1/0132/15.

\section{REFERENCES}

[1] NOVÁK, P.: Elektrické teplo, Technical University of Košice, 2010, ISBN 978-80-89284-48-1.

[2] VARGA, L. - ILENIN, S. - LEŠČINSKÝ, P.: Prenos a rozvod elektrickej energie, Technical University of Košice, 2003.

[3] MASTERS, G. M.: Renewable and Efficient Electric Power Systems, Published by John Wiley and Sons, New Jersey, 2004, ISBN 0-471-28060-7.

[4] KOLCUN, M. - BEŇA, L. - MÉSZÁrOS, A.: Optimalizácia prevádzky elektrizačnej sústavy, Technical University of Košice, 2009, ISBN 978-80553-0323-9.

[5] TKÁČ, J. - HVIZDOŠ, M.: Monitoring of solar radiation on measurement stand, 8th International Scientific Symposium, Stará Lesná, Slovak Republic 2015.

[6] BECHNÍK, B.: Fotovoltika - terminológia, Solárne novinky, 2016, http://www.solarnenovinky.sk/ technika/2014/06/04/fotovoltika-terminologia-ingbronislav-bechnik-phd

[7] Ako prevádzkovat' strešnú elektráreň $\mathrm{v}$ zime?, Solárne novinky, 2016, http://www.solarnenovinky. sk/trendy/2016/01/11/ako-prevadzkovat-stresnuelektraren-v-zime

[8] PIETRIKOVÁ, A. - BANSKÝ, J.: Základy inžinierstva materiálov, Technical University of Košice, 2007, ISBN 80-8086-001-7.

[9] AGARWAL, A.: Photovoltaics with nanotechnology, International Journal of Scientific and Engineering Research, India, 2016, ISSN 2229-5518.

[10] DORF, C. R.: Energy, resources and policy, Addinson Wesley Publishing Company Inc., 1978, ISBN 0-201-01673-7.

[11] Slovak Hydrometeorological Institute, Bratislava, 2017, http://www.shmu.sk/sk/?page=1\&id=klimat _operativneudaje1\&sub=1

[12] HAMMAMI, M. - TORRETTI, S. - GRIMACCIA, F. - GRANDI, G.: Thermal and Performance Analysis of a Photovoltaic Module with an Integrated Energy Storage System, Technical University of Bologna, 2017.

[13] KOLCUN, M. - CHLADNÝ, V. - MEŠTER, M. CIMBALA, R. - TKÁČ, J. - HVIZDOŠ, M. -
RUSNÁK, J.: Elektrárne, Technical University of Košice, 2006, ISBN 80-8073-704-5.

[14] CHLEBNÝ, J. - BENEŠ, P. - LANGER, J. KRÁL, J. - MARTINÁSKOVÁ, M.: Automatizace a automatizační technika, Computer Press Brno, 2014.

[15] GÓRECKI, K. - GÓRECKI, P. - PADUCH, K.: Modelling solar cells with thermal phenomena taken into account, Journal of Physics: Conference Series, Vol. 494, 2014, 012007, DOI:10.1088/17426596/494/1/012007, Poland, 2014.

[16] GÓRECKI, K. - KRAC, E.: Measurements of thermal resistance of solar cells, Journal of Physics: Conference Series, Vol. 709, 2016, MicroTherm'2015 and SENM'2015, 012007, pp. 16, DOI: 10.1088/1742-6596/709/1/012007, Poland, 2015.

[17] BLUMSACK, S.: Basic economics of power generation, transmission and distribution, The Pennsylvania State University, IJSER, 2014.

[18] WARATHE, S. - PATEL, R. N.: Numerical Relay Algorithm for Blackout Prevention, International Journal of Scientific and Engineering Research, India, 2016, ISSN 2229-5518.

[19] AGWA, A. M. - EISAWY, E. A. - HASSAN, H. M.: Loss of Offsite Power Probability Assessment using Fault Tree Analysis, International Journal of Scientific and Engineering Research, 2016, ISSN 2229-5518.

Received July 31, 2017, accepted December 13, 2017

\section{BIOGRAPHIES}

Vladimír Gáll was born in Kojatice, in 1988. He received the MSc. degree from Faculty of Electrical Engineering, Technical University of Košice in 2013.

Alexander Mészáros was born in Rožňava, in 1959. He received the MSc. degree from Faculty of Electrical Engineering, Technical University of Košice in 1983, and the PhD. degree from Faculty of Electrical Engineering, Technical University of Košice in 2002. Since 1996 he has been working at the Department of Electric Power Engineering, Faculty of Electrical Engineering, Technical University of Košice as an assistant professor, since 2009 as an associate professor. His major fields of interests are economic and environmental aspects of electric power systems.

Ján Tkáč was born in Košice, in 1953. He received the MSc. degree from Faculty of Electrical Engineering, Technical University of Košice in 1976, and the CSc. degree from Faculty of Electrical Engineering, Slovak Technical University Bratislava in 1986. Since 1977 he has been working at Research and Development Base of East Slovak Power Plants. Since 1977 he has been working in the Department of Electric Power Engineering, Faculty of Electrical Engineering, Technical University of Košice as an assistant professor. His major fields of interests are renewable energy sources and environmental aspects of electric power systems. 